\title{
An Empirical Study of the Impact of Service Quality for Taiwanese Firms to Enter the Chinese Market
}

\author{
Anny Ching-Fang Wei, Peir-Chyi Lii
}

Tamkang University, Chinese Taipei.

Email: anny.wei1101@msa.hinet.net

Received May, 2013

\begin{abstract}
The paper deals with the power quality analysis of interlaced four quadrants (4Q) converters with constant switching frequency. These are in fact the input stages of the locomotives and high speed trains supplied by $25 \mathrm{kV}, 50 \mathrm{~Hz}$ and 15 $\mathrm{kV}, 16.7 \mathrm{~Hz}$ lines. Due to the high power needed for the train circulation, the 4Q converters can absorb distorted currents, whose harmonic content can affect the signaling systems and communication devices. The presence of more converters gives the opportunity, using dedicated commutation strategy, to interlace them in order to reduce the harmonic content in absorbed current. In the paper a suitable model of more 4Q converters is developed. The control logic implemented in the model allows the evaluation of the harmonic contribution of both single converter and the interlaced configuration. The analysis is carried out through electromagnetic transient simulations.
\end{abstract}

Keywords: Cross-cultural Difference; Service Quality; Chinese Market; Service Contact

\section{Introduction}

Organizations have realized that being customer-oriented is fundamental to their success as satisfying customer needs is a critical mission that they have to face if they are to survive [1]. By satisfying and exceeding their customers' needs, organizations are able, through this direct chain of causation, secure their customers' loyalty, and increase their growth and profits [2]. Petty and Goodman (1996) showed that it is only right for organizations to pay commensurate level of attention to customers as they make a sizeable contribution to the profitability of these organizations. In successful organizations, profitability is a definite result of value-creation for their customers [3]. Consequently, customer loyalty holds the key to success. In order to improve customer loyalty, organizations must strive to increase customer satisfaction by elevating service quality and enhancing service value. Service quality involves relationship quality while service value encompasses relationship value [4]. Elements that constitute customer satisfaction include subjective perception of customers, emotional acceptance of products/services, service intention and overall service design. Commitments that organizations made to their customers are crucial in safeguarding customer loyalty; and these include commitment to product/service quality, to the rights and interests of customers, and to post-sales and warranty sermjyvices. Customers' subjective perception can also be affected by service fairness, service quality, trust, and business friendship that may arise from service contacts and service interactions. Customer satisfaction and perception evaluation are two main factors affecting service satisfaction. Perception of satisfaction is fast replacing physical assets as a valuable intangible asset of organizations.

\section{Research Propositions}

While providing services to customers in China, Western or European firms place great emphasis on service quality, service value and service satisfaction of their customers [5]. On the other hand, Chinese consumers look at the relationship quality, relationship benefits, and subjective perception of products/services quality from Western or European firms before being committed to these products/services. Service quality is derived from the product's ease of use, post-sales services and service contacts with sales and/or customer service personnel. Customers evaluate relationship benefits as the ratio of product price and product features. Subjective perception comprises both the physiological and psychological aspects. Physiologically, service acceptance can be increased by habits that are formed by repetitive physical actions. It is much harder to form psychological habits as one may have to take into consideration feelings and sense of trust that are evoked by the firms' commitment to quality and cus- 
tomer rights.

\subsection{Proposition 1}

Power distance differences between Western or European countries and Eastern countries, in which the former has lower power difference scores than the latter, may cause discomforts in Chinese consumers during service contacts. In Western or European countries, service interactions are commonly very cordial and done in close proximity [6]. This low power distance way of service contact may lead the Chinese consumers to perceive these Western or European firms as being too casual, even to the point of being imprudent, thus affecting the formation of customer trust.

Based on the above deduction, this study states:

Proposition 1: Chinese consumers are unable to adapt to the overly friendly service interactions that Western or European countries provide, thus lowering customer satisfaction.

\subsection{Proposition 2}

With lower uncertainty avoidance, Western or European countries are more willing to accept and take risk [7]. Comparatively, Eastern countries are less willing to do the same as they generally have higher uncertainty avoidance scores. During service interactions, Western or European firms may be more willing to promise more than they can deliver. Although there is no reason to believe that Western or European firms will shirk their commitments to their customers, Chinese consumers may not be very receptive as they may deem these promises to be given rather frivolously.

Thus this study put forth:

Proposition 2: Western or European countries might be over-committed to the Chinese consumers, thus lowering customer trust.

\subsection{Proposition 3}

Studies have shown that Westerners and Europeans are known to be competitive in their thinking and acting, while those from Eastern countries are more reserved and mild in temperament [8]. This difference in behavioral norms may prove to bean obstacle for Western or European countries while trying to break into the Chinese market. Competitive temperaments are linked to being more proactive, creative and being more on the cutting edge of technology. When applied to product designs or service interactions, it may result in advanced and/or complex approaches. The resulted complexities may cause Chinese consumers to lose patience when dealing with telephone or online customer services. They may even encounter communication problems which will cause them to judge these firms unfavorably.
Based on the argument above, this study offers:

Proposition 3: Western or European countries provide services that are too complicated for the Chinese market, testing the patience of Chinese consumers and alienating them in the process, and this will lower customer satisfaction.

\subsection{Proposition 4}

Western or European countries have higher individualism, thus they are more concerned with their individual rights and more likely to move to protect and defend those rights [9]. Eastern countries are higher in collectivism where they tend to put the interest of their communities and societies before there own and more likely to prioritize group/organizational goals. With higher individualism, firms have the tendency to favor personalized services, such as providing personalized customer service or charging more for additional post-sale services. All these may not be easily accepted in countries with high collectivism as consumers are not willing to pay extra nor do they wish for special attention. All they want is to be treated like everyone else. In this way, Chinese consumers can do a fair comparison of available services when making consumption assessment. The difference in services interactions that arise from this factor may hinder Western or European firms' entry to the Chinese market.

In this case, this study suggests:

Proposition 4: Non-standardized services provided by Western or European countries may cause the Chinese consumers to question the firms' service fairness, thus lowering customer satisfaction.

\section{Conclusions}

Cultural differences between Eastern and Western countries have an extensive effect on various human activities, including individual thought and/or behavior patterns, organization's decision-making process, and communication style [10]. Similar cultural background encourages consensus, which in turn promotes greater tolerance and easier acceptance of products/services design. Furthermore, having similar cultures help foster association and goodwill between organizations and consumers. Other than encouraging consumers to repeat consumption, emotional feedback will help to promote customer loyalty towards these organizations. Taiwan and China has similar collectivistic culture, and this can be verified through their perception of things, business management efficiency, and materialism, concept of time, collectivism, high power distance, and high uncertainty avoidance. Therefore it can be said that the close sense of identity the Chinese consumers have with Taiwanese firms and greater acceptance of Taiwanese services and/or products 
than those of Western or European countries are the result of cultural closeness between Taiwan and China. These subjective affection and favorable acceptance Chinese consumers have towards Taiwanese firms will encourage repeat consumption of their products/services and consequently constitute higher customer loyalty to Taiwanese firms. This study concludes that due to the similarity in culture and thinking processes, Taiwanese firms are better in understanding the needs of the Chinese consumers and thus enjoy greater success rate in the Chinese market.

\section{REFERENCES}

[1] Y. T. Tu and Y. L. Shean and Y. Y. Chang, "A Cross-Cultural Comparison by Individualism/Collectivism among Brazil, Russia, India and China,” International Business Research, Vol. 4, No. 2, 2011, pp. 175-182. doi:10.5539/ibr.v4n2p175

[2] W. H. Huang and A. P. Tai, "A Cross-Cultural Comparison of Customer Value Perceptions for Products: Consumer Aspects in East Asia," Cross Cultural Management Vol. 10, No. 4, 2003, pp. 43-60. doi:10.1108/13527600310797685

[3] L. Zhou, “A Dimension-specific Analysis of Performance-only Measurement of Sincerely Yours, Ervice Quality and Satisfaction in China's Retail Banking," The Journal of Services Marketing, Vol. 18, No. 6/7, 2004, pp. 534-546. doi:10.1108/08876040410561866

[4] J. Y. Qi and Y. P. Zhou and W. J. Chen and Q. X. Qu, "Are Customer Satisfaction and Customer Loyalty Driv- ers of Customer Lifetime Value in Mobile Data Services: A Comparative Cross-country Study," Information Technology and Management, Vol. 13, No. 4, 2012, pp. 281-296. doi:10.1007/s10799-012-0132-y

[5] R. Chinta and N. Capar, "Comparative Analysis of Managerial Values in the USA and China," Journal of Technology Management in China, Vol. 2, No. 3, 2007, pp. 212-224. doi:10.1108/17468770710825151

[6] M. A. Dickson, S. F. Lennon, C. P. Montalto, D. Shen and L. Zhang, "Chinese Consumer Market Segment for Foreign Apparel Products,” Journal of Consumer Marketing, Vol. 21, No. 5, 2004, pp. 301-317. doi:10.1108/07363760410549131

[7] J. T. Tu, "Cross-cultural Comparisons between Taiwan and America," Interdisciplinary Journal of Contemporary Research In Business, Vol. 2, No. 4, 2010, pp. 116-129.

[8] H. M. John and D. R. Williams-Ellis and Y. Zuo, "Cross-cultural Influences on Service Quality in Chinese Retailing: A Comparative Study of Local and International Supermarkets in China,” Asian Business \& Management, Vol. 2, No. 2, 2003, pp. 205-221. doi:10.1057/palgrave.abm.9200042

[9] K. Tian and L. Borges, "Cross-Cultural Issue in Marketing Communications: An Anthropological Perspective of International Business,” International Journal of China Marketing, Vol. 2, No. 1, 2011, pp. 110-126.

[10] C. Bianchi and J. Drennan, "Drivers of Satisfaction and Dissatisfaction for Overseas Service Customers: A Critical Incident Technique Approach,” Australasian Marketing Journal, Vol. 20, No. 1, 2012, pp. 97-107. doi:10.1016/j.ausmj.2011.08.004 